\title{
THE PALAEOLIMNOLOGY OF LOUGH MURREE, A BRACKISH LAKE IN THE BURREN, IRELAND
}

\author{
Filippo Cassina, Catherine Dalton, Elvira de Eyto and \\ Karin Sparber
}

\begin{abstract}
Lough Murree, a rock/karst barrier lagoon, is superficially isolated from the sea and seasonal variations in lake water level reflect precipitation and groundwater variation. Lake salinity is influenced by subsurface saline intrusions, occasional barrier overwash together with precipitation and groundwater inflow, leading to poikilohaline conditions. Palaeolimnological reconstructions in Murree support the supposition that the lagoon was once superficially connected to the sea around the mid-nineteenth century. Physical, chemical and biological proxies suggest an evolution to more freshwater conditions. Uncertainties about the timing of the transition persist because of an unresolved sediment chronology. The isolation of Murree from the Atlantic Ocean has promoted the formation of dense charophyte beds composed of lagoonal specialist species, which are able to tolerate large variations in salinity.
\end{abstract}

Filippo Cassina (Corresponding author; e-mail: filippo.cassina@gmail.com): Catherine Dalton and Karin Sparber, Department of Geography, Mary Immaculate CollegeUniversity of Limerick, Co. Limerick, Ireland; Elvira de Eyto, Marine Institute, Newport, Co. Mayo, Ireland.

Cite as follows: Cassina, F., Dalton, C., de Eyto, E. and Sparber, K. 2013 The palaeolimnology of Lough Murree, a brackish lake in the Burren, Ireland, Biology and Environment: Proceedings of the Royal Irish Academy 2013. DOI: 10.3318/ BIOE.2013.23

Received 28 January 2013. Accepted 19 August 2013. Published 30 December 2013.

\section{INTRODUCTION}

Coastal lagoons are typically shallow coastal water bodies located at the transition between terrestrial and marine ecosystems (Viaroli et al. 2004). In particular, lagoons are unstable and dynamic environments in the ecotone between inland freshwater and marine systems. Lagoon hydrology depends on climate variability, which exerts control on both freshwater (e.g. precipitation) and seawater (e.g. tides and sea level). Variations in water volume, salinity, temperature and water chemistry characterise lagoons, and such changes are greater than in most other aquatic environments (Healy 2003; Kennish and Paerl 2010).

Lagoons are considered to be among the most productive natural ecosystems in the world (Levin et al. 2001). However, few species are generally permanent inhabitants of such systems, and low biodiversity is generally evident in coastal lagoons (Healy 2003). This is explained by the environmental stress that is principally represented by salinity fluctuations (Bamber et al. 1992), and only euryhaline species are able to withstand such harsh conditions. In particular, some opportunistic species, largely restricted to coastal saline lakes and absent in estuaries or salt marshes, are defined lagoonal specialists (e.g. Chara canescens, Lamprothamnium papulosum) (Bamber et al. 2001) and are generally rare and legally protected (Oliver 2005).
Lagoons play an important ecological role. As many lagoons are shallow, the photic zone can sometimes extend to most of the lagoonal floor and benthic primary producers represent a large fraction of the total primary production (McGlathery et al. 2007). Shallow lagoons tend to be dominated by seagrasses, benthic algae and macrophytes, and as a result, benthic primary production often exceeds phytoplankton production (Kennish and Paerl 2010). The formation of dense benthic macroalgae and macrophyte beds leads to considerable nutrient uptake with a consequent reduction in water column nutrients (Tyler et al. 2003; Lloret et al. 2008).

Coastal lagoon ecosystems are sensitive to natural pressures (e.g. progressive sea level rise, floods and storms) as well as anthropogenic influences (e.g. land reclamation, aquaculture and eutrophication) (Airoldi and Beck 2007). Thus, these systems represent unique habitats of high conservation value, which have been included in both the EU Habitats Directive (92/43/EC) and the EU Water Framework Directive (WFD; 2000/60/EC). The WFD aims to prevent further deterioration of inland and coastal water bodies and achieve a good ecological status by 2015. Additionally, the directive requires a baseline of reference conditions prior to anthropogenic impact to be identified.

Aquatic sediments represent excellent archives of past environmental conditions as they record both autochthonous (in lake) and allochthonous (terrestrial) inputs. Palaeolimnological multidisciplinary studies have been successfully applied to coastal environments by using a wide range of 


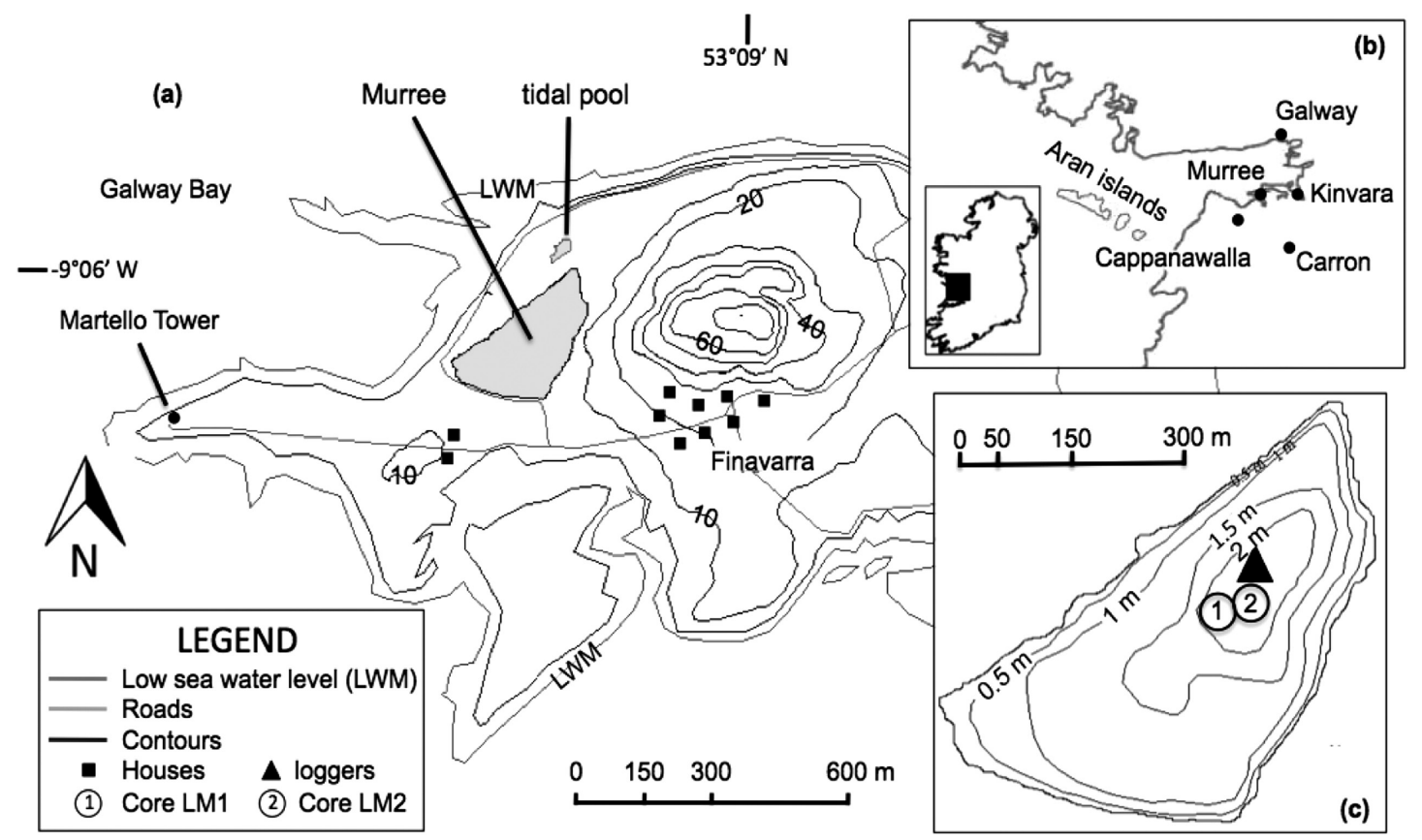

Fig. 1-(a) Map of Murree showing its location, contour lines (m) and low sea water level (LWM); (b) location of Murree, Galway, Carron, Kinvara, Cappanawalla and Aran Islands and (c) Murree bathymetry, (1) long and (2) superficial sediment cores and monitoring station position (triangle).

sediment proxies (e.g. Müller and Voß 1999; Lloyd and Evans 2002; Cearreta et al. 2003; Holmes et al. 2007; Dolukhanov et al. 2010; Savage et al. 2010), permitting inference of development and change of these coastal water systems over time. Only a few sediment studies have been conducted on coastal lagoons in Ireland (Buzer 1981; Holmes et al. 2007; Cassina et al. 2013).

The purpose of this study is to provide a detailed understanding of Lough Murree (Co. Clare), a karst lagoon on the western coast of Ireland, from a palaeolimnological perspective. Lithology, stable isotopes and a number of biological fossils (e.g. diatoms, foraminifera and ostracoda) have been analysed to track the ecological history of the lagoon in response to coastal influence. Reconstructing the past requires a detailed understanding of the current hydrological regime (e.g. salinity) in order to understand system evolution through time. Thus, palaeolimnological reconstruction was augmented by monitoring modern hydrology (i.e. salinity and temperature) through the water column over a two-year period in order to accurately delineate the hydrological changes of these coastal ecosystems and support inferences of lagoon ontogeny.

\section{STUDY SITE}

Lough Murree is a shallow coastal lake situated on the south shoreline of Galway Bay (N53 $09^{\prime} 13^{\prime \prime}$,
W09 $06^{\prime} 46^{\prime \prime}$ ) on Finavarra Peninsula and the northern edge of the Burren, a karst-landscape region in northwest County Clare (Fig. 1b). The lake is included in the Galway Bay complex Special Area of Conservation (SAC; site code 268) under the EU Habitats Directive (92/43/EEC). The Burren, together with the Aran Islands, constitutes an exceptional karstic limestone region in Atlantic Europe with glacial deposits, high flora diversity and archaeological evidence of human occupation from the Neolithic (4000 year BC) onwards (Molloy and O'Connell 2004). The area is characterised by Carboniferous limestone that fringes the southern sides of Galway Bay and extends into the sublittoral zone. Kinvara (c. 12km from Murree) represents the focal point for a large part of the underground drainage from the north Burren lowlands (Cave and Henry 2011). Submarine and intertidal karst springs can be observed along the coastline and groundwater resurgences have been identified (Mullan 2003; Cave and Henry 2011).

The lagoon catchment is small (c. $\left.4.3 \mathrm{~km}^{2}\right)$, with a maximum altitude of $67 \mathrm{~m}$ to the north-east. Most of the surrounding region is classified as improved pasture and rough grazing (cattle) predominates (CORINE 1990). Surface drainage is limited due to the karstic nature of the bedrock. Murree is isolated from the sea, and its morphology resembles isolation basins present along the rocky shores of Scotland and Norway (e.g. Lloyd and Evans 2002; Balascio et al. 2011). Lough Murree is 
formed in limestone bedrock on which a cobble barrier has been deposited along the coastal boundary (Healy et al. 1997). The stretch of land separating the lake from the sea is generally above the highest tidal level with the exception of the south-western edge, which dips below the level of the coastal road. To the north, karst landforms prevail with a fissured limestone pavement and a small tidal pool, which fills and empties at each tidal cycle illustrating underground connections with the sea (Pybus and Pybus 1980). Pybus and Pybus (1980) suggested that Murree had a surface communication with the adjacent ocean at its southwestern shore in the past.

Murree is classified as a karst lagoon (Oliver 2007), and it lies on a north-east-south-west transect. It is approximately $600 \mathrm{~m}$ long and $300 \mathrm{~m}$ wide with a total area of $c .13 .6$ ha. The bathymetry, determined in 2009 as part of this study, shows a shallow basin with a mean depth of $1.3 \mathrm{~m}$. The deepest area is located to the north-east with a maximum depth of $2.2 \mathrm{~m}$. The lake water level is below the high spring tide level, thus enabling seawater intrusion into the lake at high tide (Geoff Oliver, pers. comm.) Therefore, it can be assumed that the lake water level approximates the height of mean low tide (i.e. Om OD).

The lake was described in 1965 as a naturally eutrophic lake with dense algal mats and algal blooms (Lansbury 1965). However, low annual average phosphorus (10ìg $\mathrm{P}^{-1}$ ) and nitrogen concentrations $\left(0.1 \mathrm{mg} \mathrm{N}^{-1}\right)$ were reported in 1980 (Pybus and Pybus 1980) and recently confirmed by Roden and Oliver (2010). During spring, summer and autumn, the water column is highly transparent with an abundance of macrophytes and macroalgae. Murree has a high conservation rating because it is an unusual lagoon morphological type with a rich aquatic flora (20 floral taxa) (Healy et al. 1997; NPWS 2001). Typical brackish water plants characterise the lake including tasselweeds (Ruppia cirrhosa and Ruppia maritima) and Potamogeton pectinatus, which cover large areas of the lake surface (Healy et al. 1997). Additionally, two rare charophytes, Lamprothamnion papulosum and Chara canescens, form dense beds in the shallower areas (Oliver 2005). Poor faunal diversity is evident in Murree despite the presence of diverse habitats and substrates (Healy et al. 1997; Oliver 2007). In total 25 taxa (mainly hydrobidae and isopoda) were recorded, and most of them were classified as poly-mesohaline and euryhaline species. Some species were listed as lagoonal specialists such as the Sigara stagnalis and the beetle Enchorus halophilus (Healy et al. 1997). Empty shells of barnacles on rocks indicate that a more saline environment existed in the past.

\section{MATERIALS AND METHODS}

MODERN HYDROLOGY

A monitoring station composed of three DST CT Star-Oddi Data Storage sensors was installed to monitor temperature and salinity in the water column of Murree (Fig. 1c). Recorders were positioned at $0.5 \mathrm{~m}, 1 \mathrm{~m}$ and $1.5 \mathrm{~m}$ depths, and hourly measurement intervals were set for both parameters. Data retrieval was carried out by means of Sea Star 4.3.8 (Star-Oddi 2001) software. Data were collected between February-October 2009 and February-July 2010. Rainfall and air temperature data are from Carron (Co. Clare; N53 02'19", W09 $03^{\prime} 18^{\prime \prime}$; c. $13 \mathrm{~km}$ from Murree; Met Éireann, unpublished data), while tidal data are from the Galway Port (N53 16'08', W09 02'53"; c. $12 \mathrm{~km}$ from Murree; Met Éireann, unpublished data) (Fig. 1b).

\section{PALAEOLIMNOLOGY}

Two sediment cores were collected from the deepest part of the lake in 2009 (Fig. 1c). A surface sediment core $(35 \mathrm{~cm}$; LM1) was collected using a gravity corer (Renberg and Hansson 2008), and a $116 \mathrm{~cm}$ long core (LM2) was collected using a Livingstone corer (1955) from the same area. Sediment cores were extruded and subsampled at $1 \mathrm{~cm}$ resolution.

\section{Sediment chronology}

LM1 core was dated using radiometric technique $\left({ }^{210} \mathrm{~Pb},{ }^{137} \mathrm{Cs}\right.$ and $\left.{ }^{241} \mathrm{Am}\right)$ at the Bloomsbury environmental isotope facility (BEIF), University College London. Samples were analysed using an ORTEC HPGe GWL detector. Dates were determined using the constant rate supply (CRS) model (Krishnaswami et al. 1971; Appleby and Oldfield 1978), while sediment accumulation rates (SARs) were calculated using unsupported ${ }^{210} \mathrm{~Pb}$ and expressed both as $\mathrm{g} \mathrm{cm}^{-2}$ year -1 and $\mathrm{cm}_{\text {year }}-1$.

Accelerated mass spectrometry (AMS) radiocarbon analysis was performed at the CHRONO Centre, Queen's University Belfast. A range of macrofossils from the core LM2 were analysed (wood, charcoal and carbonate fossils such as foraminifera tests and Cerastoderma glaucum shells) with appropriate pre-treatments as no single fossil occurred repeatedly over the core sequence. Calibration of radiocarbon dates was conducted using Calib 6.0 software (Stuiver et al. 2005). Radiocarbon results are expressed as radiocarbon age BP and calibrated results as calibrated years BP (cal. year BP). Radiocarbon ages from terrestrial fossils (i.e. wood and charcoal) were calibrated using IntCal09 calibration curve, while Marine09 was adopted to calibrate carbonate samples (Reimer 
et al. 2009). The marine reservoir effect $(\Delta R=$ $-111 \pm 18$ ) from the site DL3 (Connemara Coasts) proposed by Ascough et al. (2009) was assumed. A mixed calibration curve (Reimer et al. 2009) was additionally run for carbonate samples. Two sigma $(2 \sigma)$ age ranges were utilised as recommended by Björck and Wolhlfarth (2001).

\section{Lithostratigraphy and stable isotopes}

Variations in lithological composition were initially identified through sediment cores by visual inspection. Loss on ignition was measured shortly after collection to estimate organic matter and carbonate content $\left(\mathrm{LOI}_{550}\right.$ and $\left.\mathrm{LOI}_{950}\right)$ (Heiri et al. 2001).

Carbon and nitrogen stable isotopes sample preparation was based on the combination of methods proposed by Talbot (2001) and Wolfe (2001). The analysis was carried out at the Geochemistry Laboratory, Trinity College, Dublin, using a thermo delta continuous flow isotope ratio mass spectrometer (CF-IRMS) and International Atomic Energy Authority reference standards. Elemental weight percentage composition of organic carbon $\left(\mathrm{C}_{\text {org }}\right)$ and total nitrogen $\left(\mathrm{N}_{\text {tot }}\right)$ was used to calculate the $\mathrm{C} / \mathrm{N}$ ratio. Stable isotope results are reported as organic carbon $\left(\delta^{13} \mathrm{C}\right)$ and nitrogen $\left(\delta^{15} \mathrm{~N}\right)$. Correlations between $\delta^{15} \mathrm{~N}, \mathrm{C} / \mathrm{N}$ ratio and nitrogen (\%) were calculated to test for the presence of sediment diagenetic processes (Thornton and Mc Manus 1994) using SigmaPlot 11.0. Salinity reconstruction was derived from $\delta^{13} \mathrm{C}$ measurements according to the equation: salinity $\%=\left(\delta^{13} \mathrm{C}+\right.$ 30.5)/0.54 (Emeis et al. 2003).

\section{Fossil diatoms}

Fossil diatoms were prepared according to Battarbee et al. (2001). Identification and enumeration were achieved using a Leica DME microscope with oil immersion objective at $1000 \times$ magnification. Fossil records were biased by preservation and dissolution issues, with a minimum count of just 200 valves achieved for each sample. Taxonomic identification was derived using the Snoejis series (Snoeijs 1993; Snoeijs and Vilbaste 1994; Snoeijs and Potapova 1995; Snoeijs and Kasperovièienë 1996; Snoeijs and Balashova 1998) and Krammer and Lange-Bertalot (Krammer and Lange-Bertalot 1986; 1988; 1991a; 1991b; 2000) floras. A total of 11 and 30 taxa had abundances $>1 \%$ and occurred in more than two samples in LM1 and LM2 cores, respectively. Problems were experienced in classifying many genera to species level. The diatom morphological dissolution index (F index) (Flower and Lokhoshway 1993; Ryves et al. 2006) was calculated to quantify frustule dissolution. Diatom taxa were divided into groups according to their salinity tolerance and life forms. Zonation of diatoms was performed with constrained cluster analysis (CONISS) by means of Psimpoll 4.27 software (Bennett 2008), and the number of significant zones was identified by applying the broken-stick model (Bennett 1996).

\section{Foraminifera and ostracoda analysis}

Foraminifera and ostracoda sample preparation followed the methods in De Deckker (1982) and Holmes (2001). Specimens were picked and transferred to Chapman slides under a Meiji optical stereoscope at $45 \times$ magnification. Concentrations were calculated for foraminifera (tests $\mathrm{g}^{-1} \mathrm{WW}$ ) and ostracoda (shells $\mathrm{g}^{-1} \mathrm{WW}$ ). Foraminifera were classified to species level following Murray (1979), Horton and Edwards (2006) and Scott et al. (2007). The percentage of noded valves of Cyprideis torosa was calculated (Keatings et al. 2007); however, due to very low concentrations in the deeper sediments only samples above $c .40 \mathrm{~cm}$ were examined. Population structure was also investigated by measuring biometric dimensions (i.e. length and height) of the dorsal view of at least 120 shells at three example core intervals. Subdivisions between adults and juvenile instars were derived according to Heip (1976) and Meisch (2000). Charcoal particles and Characeae oospores were encountered during the work and were also enumerated with concentrations expressed as number per $\mathrm{g}^{-1} \mathrm{WW}$.

\section{RESULTS}

\section{MODERN HYDROLOGY}

Salinity ranged from $0 \%$ to $30 \%$ over the study period, and its stratification to the lake bottom was evident despite the shallow nature of the Murree Basin (Fig. 2c). Salinity stratification, however, was interrupted by a number of temporary isohaline events. In particular, salinity close to freshwater conditions $(0.5 \%$ ) is evident in March and April 2009. Salinity stratification reached values of $16 \%$ $18 \%$ in April 2009, and a further reduction (salinity $<10 \%$ o was apparent in May 2009. Permanent stratification is then evident from approximately mid-June to the end of October with salinities up to $25 \%$ at the base of the water column and c. $10 \%$ in the mixolimnion. A similar trend occurred in 2010 with the lowest salinity $(<1 \%$ ) recorded from February to the beginning of April. Rapid salinity shifts were also recorded with changes from $15 \%$ to almost freshwater conditions $(<1 \%)$ in only six days.

Rainfall was undoubtedly a key influencing factor on water column salinity levels; however, a comparison between salinity and rainfall (Fig. 2a) suggested an indirect relationship. This could indicate that salinity shifts are principally driven by underground freshwater flows in Lough Murree. Tidal influence was additionally explored for the 

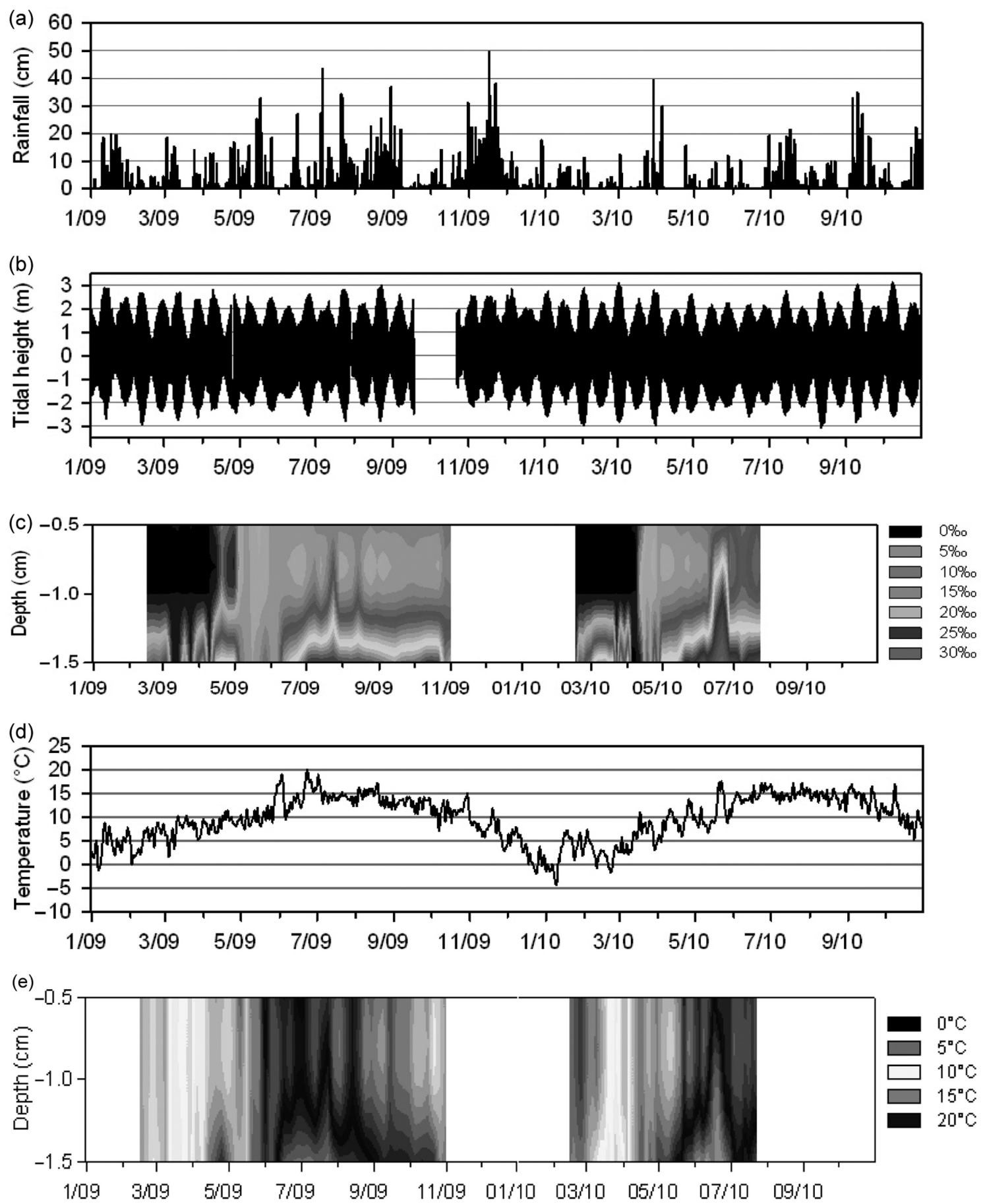

Fig. 2-(a) Rainfall from Carron (cm), (b) tidal range from Galway Port (m), (c) Murree water salinity (\%o), (d) air temperature from Carron $\left({ }^{\circ} \mathrm{C}\right.$ ) and (e) Murree water temperature $\left({ }^{\circ} \mathrm{C}\right)$ in 2009 and 2010.

whole recording period, and no direct association with water column salinity was found even during spring tides. A complex hydrology due to the karst bedrock and the presence of underground communication with the tidal pool might buffer the tidal effect on the water column.

Lake water temperature ranged between $0^{\circ} \mathrm{C}$ and $21^{\circ} \mathrm{C}$ and appeared to be closely related to air temperature (Fig. 2d and e). Water temperatures were higher than air temperature with differences up to $7^{\circ} \mathrm{C}$. Water temperature is related to salinity stratification. Isothermal conditions from February to June 2009 are interrupted by a temporary increase in temperatures to $14^{\circ} \mathrm{C}$ at the lake bottom at the end of April, which corresponds to a temporary salinity peak. Warming of the basal 


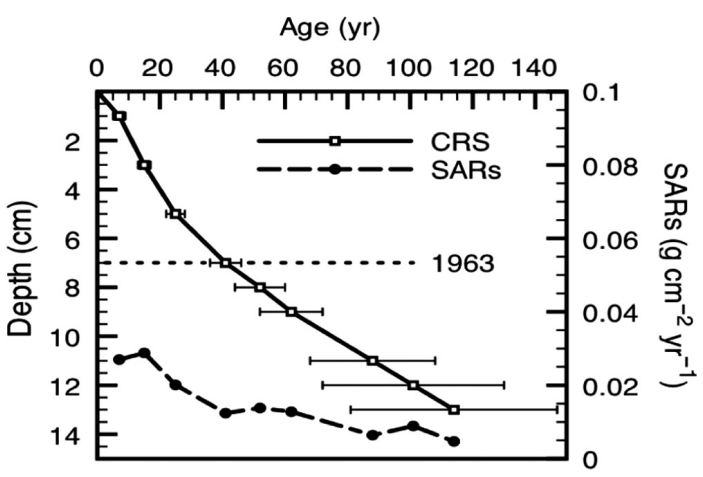

Fig. 3- ${ }^{210} \mathrm{~Pb}$ age-depth model and sediment accumulation rates (SARs) $\left(\mathrm{g} \mathrm{cm}^{-2}\right.$ year $\left.^{-1}\right)$ from LM1 core.

water column is evident from May to October coincident with salinity stratification and maximum air temperatures (Met Éireann, unpublished data). Similar trends are evident in 2010.

\section{PALAEOLIMNOLOGY}

\section{Chronology and SARs}

Establishing a chronology for Murree proved complex as two dating methods were applied to two adjacent but separate sediment cores and additional problems arose during sample selection for ${ }^{14} \mathrm{C}$ analysis.

${ }^{210} \mathrm{~Pb}$ radiometric analysis was carried out on LM1 core as it retained an intact sediment water interface. The equilibrium between the total and supported ${ }^{210} \mathrm{~Pb}$ activity is evident at approximately $15 \mathrm{~cm}$ depth, while the CRS model suggested that the top $13 \mathrm{~cm}$ represents the past 115 years (Fig. 3). Artificial radionuclides were used as independent tracers and are in good agreement with ${ }^{210} \mathrm{~Pb}$. Both ${ }^{137} \mathrm{Cs}$ and ${ }^{241} \mathrm{Am}$ place the 1963 layer at $7 \mathrm{~cm}$, while the CRS model places it at $8 \mathrm{~cm}$. SARs are low, and a progressive increase is evident from $0.057 \mathrm{~cm}$ year $^{-1}\left(0.0047 \mathrm{~g} \mathrm{~cm}^{-2}\right.$ year $\left.^{-1}\right)$ at $13 \mathrm{~cm} \mathrm{to}$ $0.095 \mathrm{~cm} \mathrm{year}^{-1}\left(0.012 \mathrm{gcm}^{-2}\right.$ year $\left.{ }^{-1}\right)$ at $7 \mathrm{~cm}$. A further rise is present from $5 \mathrm{~cm}$ up to the core top with the highest rates reached at $3 \mathrm{~cm}$ depth $\left(0.245 \mathrm{~cm} \mathrm{year}^{-1} ; 0.0028 \mathrm{~g} \mathrm{~cm}^{2}\right.$ year $\left.^{-1}\right)$ (Fig. 3).
Radiocarbon dating was carried out on four macrofossil samples through LM2 core to reconstruct older time periods. The core top was disturbed during coring, therefore, a surface sediment date could not be inferred. Radiocarbon dates for Murree are listed in Table 1, and unusually all samples date to c. 4100-4600 year BP.

No coherent sediment chronology was established due to age similarities of the radiocarbon samples. Extrapolation of the ${ }^{210} \mathrm{~Pb}$-derived accumulation rates to $111 \mathrm{~cm}$ sediment depth suggests an age of $c .1380$ cal. year BP and is thus well below the dates derived using radiocarbon methods.

Many attempts were conducted to establish a temporal overlap between LM1 and LM2 using proxies, but finding an unequivocal match proved impossible.

A possible temporal overlap between LM1 and LM2 is evident in lithology and stable isotopes suggesting that $c .17 \mathrm{~cm}$ of the top of LM2 might have been lost. A comparison of diatoms in the sediment cores illustrated many differences while no foraminifera were common to both cores. Only Cyprideis torosa and charcoal concentrations appeared similar in both cores. Thus, while the sediment cores were collected from adjacent areas $\left(<2 \mathrm{~m}^{2}\right)$, and it was estimated that a relatively small amount of sediment $(c .15-20 \mathrm{~cm})$ was disturbed or lost in LM2 the results suggest complex sediment responses or patchiness in a relatively small geographical area. Sediment data are presented stratigraphically on a depth scale for both cores, while ${ }^{210} \mathrm{~Pb}$ chronology is also shown for LM1.

\section{Lithology and stable isotopes}

The lagoon sediments were mainly organic mud with brownish black colour (Hue 10YR 3/2; Oyama and Takehar 1967), while the surface core had a mixture of mud and sand at the top. Abundant Hydrobia cf. ventrosa shells characterised LM1 sediments.

Marked variations in $\mathrm{LOI}_{550}$ are shown in core LM1 (Fig. 4a). A sharp decrease in the organic content to c. $5 \%$ is evident mid-core. An abrupt peak follows at $c .15 \mathrm{~cm}$ depth with values up to $c$. $50 \%$, while the core top averages $27 \%$. A similar

Table $1-\delta{ }^{13} \mathrm{C},{ }^{14} \mathrm{C}$ dates and calibrated $2 \sigma$ ranges in LM2.

\begin{tabular}{|c|c|c|c|c|c|}
\hline Depth (cm) & Sample & $\delta^{13} C(\%)$ & ${ }^{14} \mathrm{C}$ age (year $\left.B P\right)$ & Calibration curve & $2 \sigma$ range (cal. year $B P$ ) \\
\hline 39 & Charcoal & -24.9 & $4163 \pm 22$ & IntCal09 & $4589-4827$ \\
\hline \multirow[t]{2}{*}{43} & Foraminifera & -0.5 & $4550 \pm 31$ & Marine09 & $4502-4776$ \\
\hline & & & & Mixed & $4880-5236$ \\
\hline \multirow[t]{2}{*}{86} & C. glaucum & -0.4 & $4527 \pm 33$ & Marine09 & $4435-4767$ \\
\hline & & & & Mixed & $4861-5213$ \\
\hline 111 & Wood & -27.9 & $4475 \pm 21$ & IntCal09 & $4980-5284$ \\
\hline
\end{tabular}



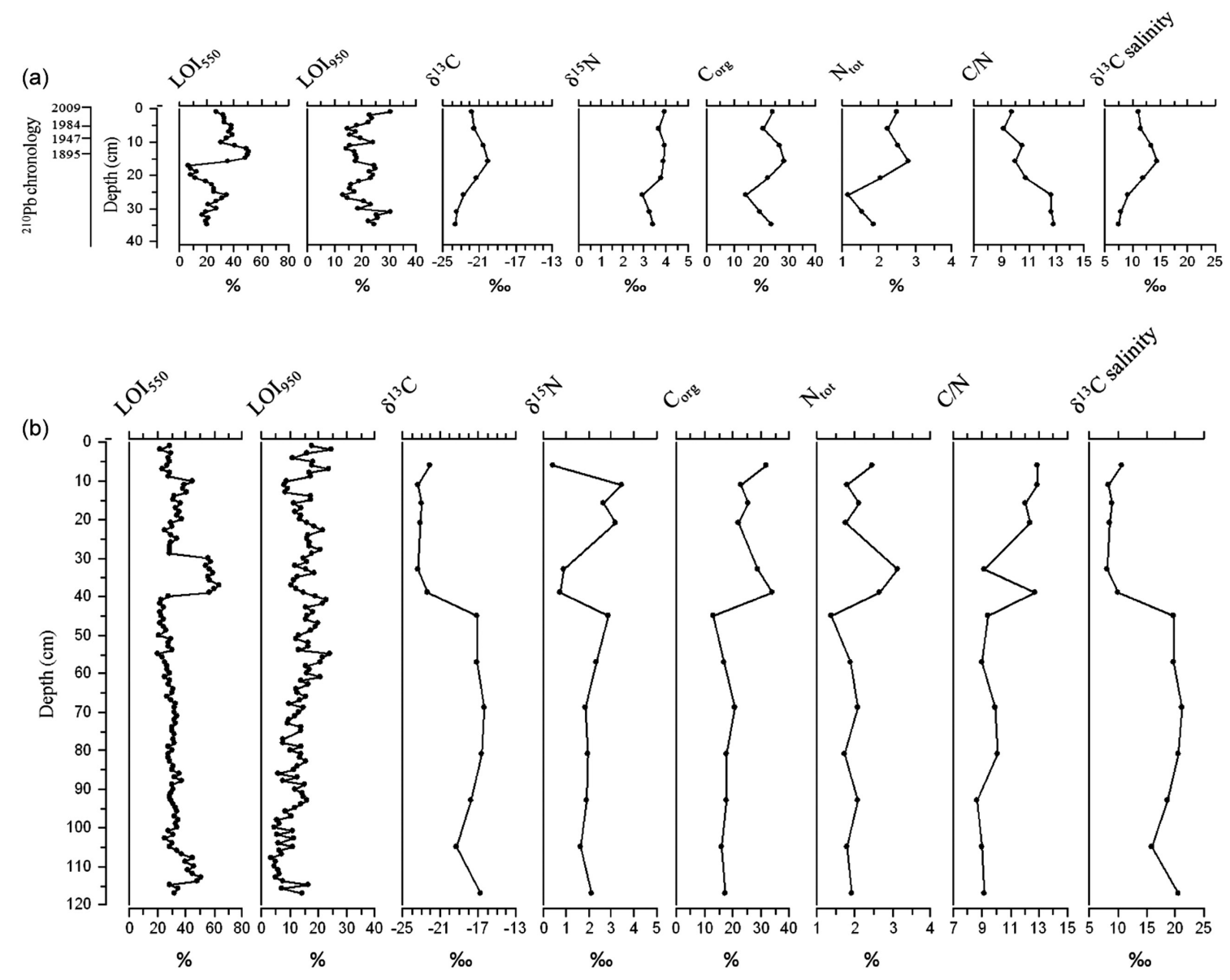

Fig. 4-(a) Organic matter content $\left(\mathrm{LOI}_{550}\right)$, carbonates $\left(\mathrm{LOI}_{950}\right)$, stable isotopes $\left(\delta^{13} \mathrm{C} \& \delta^{15} \mathrm{~N}\right)$, organic carbon $\left(\mathrm{C}_{\text {org }}\right)$ total nitrogen $\left(\mathrm{N}_{\text {tot }}\right)$ and $\delta^{13} \mathrm{C}$-inferred salinity in LM1; (b) Organic matter content $\left(\mathrm{LOI}_{550}\right)$, carbonates $\left(\mathrm{LOI}_{950}\right)$, stable isotopes $\left(\delta^{13} \mathrm{C} \& \delta^{15} \mathrm{~N}\right)$, organic carbon $\left(\mathrm{C}_{\mathrm{org}}\right)$ total nitrogen $\left(\mathrm{N}_{\text {tot }}\right)$ and $\delta^{13} \mathrm{C}$-inferred salinity in LM2.

pattern is shown by core LM2 (Fig. 4b), where $\mathrm{LOI}_{550}$ content progressively decreases from $c$. $50 \%-20 \%$ at $40 \mathrm{~cm}$. An abrupt shift to over $60 \%$ is evident between $40 \mathrm{~cm}$ and $30 \mathrm{~cm}$. The jelly-like sediment consistency of this section possibly suggests the development of microbial mats (Ladakis et al. 2006). A sample almost entirely composed of sand is also evident at $33 \mathrm{~cm}$. LOI 550 declined to $30 \%$ at the core top. No clear trends of $\mathrm{LOI}_{950}$ are evident through LM1 core, ranging between 15\% and30\% (Fig. 4a). An overall increase in $\mathrm{LOI}_{950}$ is evident in core LM2 from c. $5 \%$ at the bottom to $c .20 \%$ at $40 \mathrm{~cm}$, while the core top averages $15 \%$ (Fig. 4b).

A major change at $c .40 \mathrm{~cm}$ depth is evident in $\delta^{13} \mathrm{C}, \delta^{15} \mathrm{~N}, \mathrm{C}_{\text {org }}$ and $\mathrm{N}_{\text {tot }}$ in core LM2 (Fig. $4 \mathrm{~b}$ ). Below this depth, $\delta^{13} \mathrm{C}$ is stable with values averaging around $-17.0 \%$, while in the upper part of the core a reduction to c. $-23.0 \%$ is apparent. An increase in $\delta^{13} \mathrm{C}$ to $-19.9 \%$ is evident in LM1 with a reduction to the top ($21.7 \%$ ) (Fig. $4 \mathrm{a}$ ). $\delta^{15} \mathrm{~N}$ measured at the base of the LM2 core is around $2.0 \%$ and lows in $\delta^{15} \mathrm{~N}$ are evident between $40 \mathrm{~cm}$ and $30 \mathrm{~cm}$ and at the core top with values of $0.7 \%$ on average. In LM $1 \delta^{15} \mathrm{~N}$ is stable around $3.5 \%$. A parallel trend is evident for $\mathrm{C}_{\text {org }}$ and $\mathrm{N}_{\text {tot }}$ in LM2 with values of c. 17\% and 2\% below $40 \mathrm{~cm}$, respectively. Above this depth, an increase is evident for both $\mathrm{C}_{\mathrm{org}}\left(\right.$ c. 25\%) and $\mathrm{N}_{\text {tot }}$ (c. 2\%). Similar trends are evident in LM1. Through the core $\mathrm{LM} 2$, the $\mathrm{C} / \mathrm{N}$ ratio is stable around $9 \mathrm{C} /$ $\mathrm{N}$ and an increase to $c .13 \mathrm{C} / \mathrm{N}$ characterises the core top above $40 \mathrm{~cm}$. Similar values are found in LM1 followed by a reduction to c. 9 which characterises the most recently deposited sediments. $\delta^{13} \mathrm{C}$-inferred salinity indicates a reduction from $19 \%$ to $9 \%$ at this stratigraphic change-point.

\section{Diatoms}

Fossil diatom identification and enumeration proved difficult because of poor preservation with up to $60 \%$ of taxa unclassified. Diatom preservation was biased by silica dissolution process, determined by a number of possible factors (e.g. low concentrations of dissolved silica in water, alkalinity and bioturbation) determining selective dissolution 

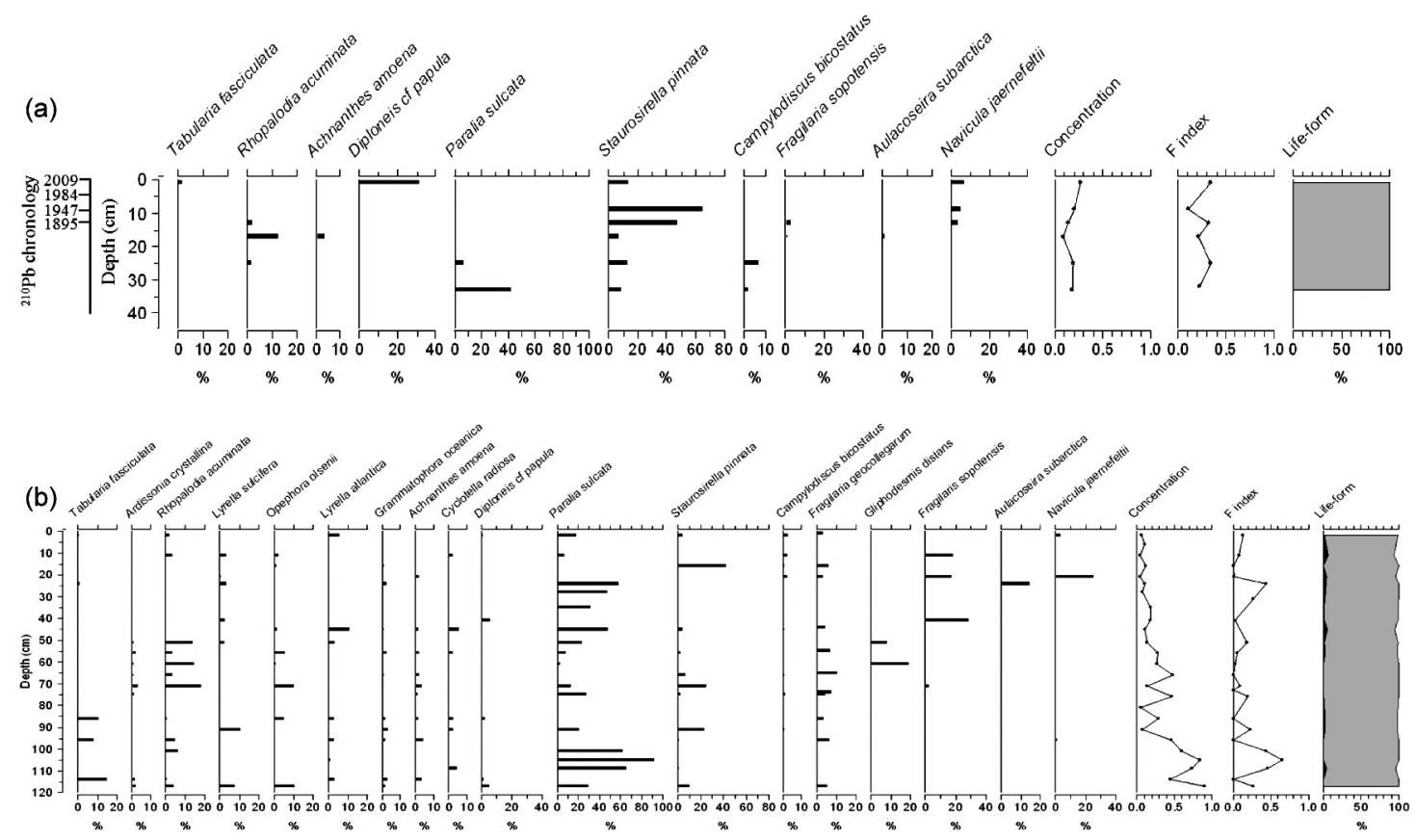

Fig. 5-(a) Summary of select diatom taxa $(n=10 ;>10 \%)$ in Murree LM1 sediment cores, concentration (frustules $\times$ $10^{5} \mathrm{~g}^{-1} \mathrm{WW}$ ), F index, salinity groups and life-form (black: planktonic; grey: benthic); (b) Summary of select diatom taxa $(n=10 ;>10 \%)$ in Murree LM2 sediment cores, concentration (frustules $\left.\times 10^{5} \mathrm{~g}^{-1} \mathrm{WW}\right), \mathrm{F}$ index, salinity groups and life-form (black: planktonic; grey: benthic).

(Reed 2007; Flower and Ryves 2009). Only robust and strongly silicified valves (e.g. Paralia sulcata, Lyrella atlantica, Rhopalodia acuminata) were generally preserved intact in Murree sediments, while other taxa presented a strong degree of silica dissolution, often limiting taxonomical classification to genera level (Fig. 5a and b). The F dissolution index was generally $<0.5$ in both cores, confirming poor frustule preservation, which precluded the application of quantitative reconstructions using transfer functions and core correlation. Diatom frustule concentrations are low and range between $0.06 \times 10^{5}$ frustules $\mathrm{g}^{-1} \mathrm{WW}$ to $9.00 \times 10^{5}$ frustules $\mathrm{g}^{-1} \mathrm{WW}$. However, despite preservation issues, a clear upcore decrease in valve concentrations is evident in LM2 core and is confirmed in LM1 core.

No significant zones of change were identified in the fossil assemblages. P. sulcata is the dominant species with highest abundances (90\%) at the base of LM2 core along with Tabularia fasciculata, Opephora olsenii, Rhopalodia acuminata and Staurosirella pinnata. The core top $(40-0 \mathrm{~cm})$ is dominated by Staurosirella pinnata (40\%), Fragilaria of. sopotensis (18\%), Navicula jaernefeltii (24\%) and Aulacoseira subarctica (13\%), while $P$. sulcata reduces to $18 \%$. LM1 core also captures the Staurosirella pinnata expansion and the decline in P. sulcata. Diploneis cf. papula and Rhopalodia acuminata are also important. Brackish and marine species dominate the bottom of LM2 core, while brackish-freshwater species increase to the core top. Brackish taxa characterise the recent sediments in LM1 (c. 115 years). Benthic taxa characterise the Murree sediment cores, while planktonic taxa are less abundant in LM2 and are absent in LM1.

\section{Foraminifera}

Foraminifera test preservation was generally good. Low biodiversity characterised Murree sediments with seven foraminiferal species found (Fig. 6a and b). Most of the taxa are infaunal, and all are benthic calcareous forms typical of marginal marine environments of Europe and are dominant in brackish waters (Murray 2006). The species in Murree are all herbivores (Murray 2006). The most common species are Ammonia aberdoveyensis (Haynes 1973) and Elphidium williamsoni (Haynes 1973). The former is dominant at the base of LM2, while the latter dominates more recent sediments in LM2 (above $30 \mathrm{~cm}$ ) and LM1. Haynesina germanica (Ehrenberg 1840) is generally subdominant. Elphidium crispum (Linné) and Elphidium macellum (Fitchel and Moll) are generally evident in the middle part of the core LM2. A. aberdoveyensis is dominant in the surficial sediments of the core LM1. Differences between the cores include low concentrations of $H$. germanica and the presence of Cibicides lobatulus (Walker and Jacob 1798) in LM1. Foraminifera concentrations fluctuate but are generally higher in LM2 bottom with the highest concentration (395 tests $\mathrm{g}^{-1} \mathrm{WW}$ ) recorded. Between $40 \mathrm{~cm}$ and $30 \mathrm{~cm}$ 


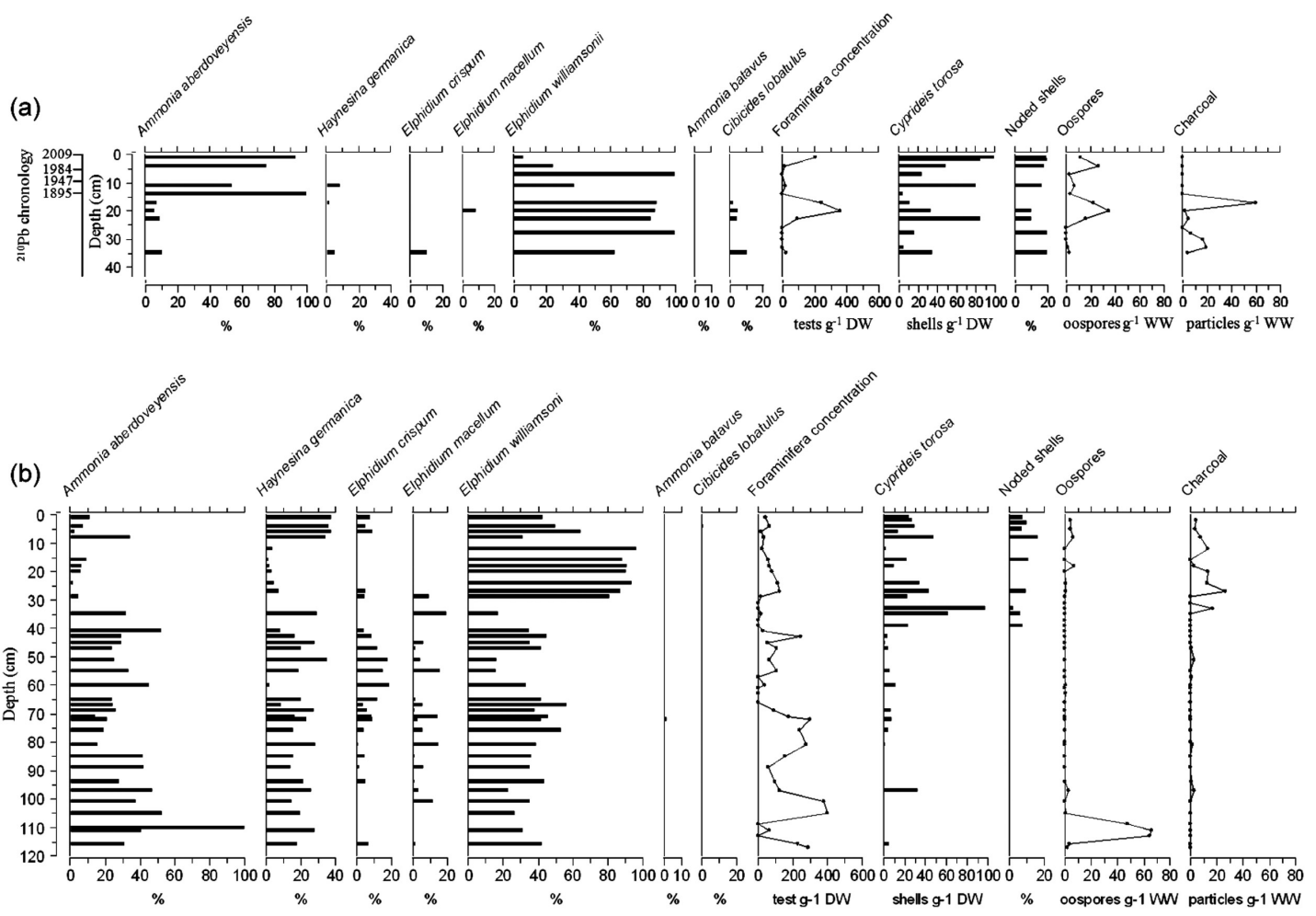

Fig. 6-(a) Foraminifera distribution (\%) and concentration (tests $\left.\mathrm{g}^{-1} \mathrm{WW}\right)$, Cyprideis torosa concentration (shells $\mathrm{g}^{-1}$ WW), C. torosa noded shell abundance (\%), Chara oospores (oospores $\mathrm{g}^{-1} \mathrm{WW}$ ) and charcoal (particles $\left.\mathrm{g}^{-1} \mathrm{WW}\right)$ in LM1; (b) Foraminifera distribution (\%) and concentration (tests $\left.\mathrm{g}^{-1} \mathrm{WW}\right)$, Cyprideis torosa concentration (shells $\mathrm{g}^{-1} \mathrm{WW}$ ), C. torosa noded shell abundance (\%), Chara oospores (oospores $\mathrm{g}^{-1} \mathrm{WW}$ ) and charcoal (particles $\mathrm{g}^{-1} \mathrm{WW}$ ) in LM2.

foraminifera are almost absent, while above $30 \mathrm{~cm}$ concentrations are generally below 100 tests $\mathrm{g}^{-1}$ WW. Test concentration in LM1 is also low but peaks of up to 360 tests $\mathrm{g}^{-1} \mathrm{WW}$ are evident.

\section{Ostracoda}

Monospecific populations of Cyprideis torosa (Jones 1950) were found in both sediment cores (Fig. 6a and b). Concentrations increase upcore in LM2. Below $40 \mathrm{~cm}$, shells are generally absent in many samples and concentrations increase from this point onwards. High concentrations $\left(>80\right.$ shells $g^{-1}$ WW) are recorded above $40 \mathrm{~cm}$ in LM2 and more frequently in LM1.

Biometric dimensions of the different moults were measured to explore potential changes in population structure (Holmes 2001; Ruiz et al. 2003) at three core intervals. In LM2 juvenile instars are only present at $54 \mathrm{~cm}$, while the population structure at $34 \mathrm{~cm}$ depth is composed of both juvenile stages and adults. Juveniles and adults were evident at the top of core LM1. Noded shells ranged between $0 \%$ and $20 \%$ in both cores with slightly higher values in the core LM1 and no clear trends are evident. Equal proportions of left- and right-oriented valves are present in both sediment cores.

\section{Oospores and charcoal}

Charophyte species produce oospores that are preserved in the sediment as propagule banks, representing a regenerative strategy for repopulating lakes (Bonis and Grillas 2002; Combroux and Bornette 2004). Oospores were found at the bottom of core LM2 with a peak up to 66 oospores $\mathrm{g}^{-1} \mathrm{WW}$ (Fig. 6b). Few oospores were found in the remainder of the core. Concentrations up to 35 oospores $\mathrm{g}^{-1} \mathrm{WW}$ are evident in LM1 (Fig. 6a).

Charcoal particles are indicative of either natural or anthropogenic fire activity. Particles are evident in LM1 and at the top of LM2 with concentrations ranging between 10 and -60 particles $\mathrm{g}^{-1} \mathrm{WW}$ (Fig. 6a and b).

\section{DISCUSSION}

\section{MODERN HYDROLOGICAL DYNAMICS AND ECOLOGY}

The contemporary hydrology in Murree reflects the karst limestone geology, which is subject to submarine groundwater discharge with inputs of fresh water to coastal zones and recharge with saline incursions (Cave and Henry 2011). Ground-water discharge and saline recharge help to maintain water 
budgets of coastal lakes and dissolved chemical constituents affect the salinity and play a role in the biological species composition and productivity (Barlow 2003).

It is clear from the hourly time series data that Murree is predominantly dependent on underground freshwater inflow. The trend of salinity stratification appears similar in both years, while higher salinity at the bottom of the water column (up to $30 \%$ ) is evident in 2010 as a result of reduced precipitation. Extreme variations in salinity were found seasonally in the lake and are reliant on the amount of winter precipitation. Isohaline conditions through the water column appeared five times from March to June 2009, while lower precipitation patterns in 2010 determined reduced salinity events from April to May. The speed of salinity change, for example, six days, at the sediment-water interface is additionally noteworthy. These dynamic conditions can prove difficult for benthic invertebrates, as documented by a recent biological survey of 18 Irish lagoons (Roden and Oliver 2010).

Despite its shallowness, Murree appeared to undergo thermal stratification during summer months mainly due to decreased precipitation, increased evaporation and underground saltwater inflow. Up to $7^{\circ} \mathrm{C}$ differences between water and air temperatures were evident during summer lake stratification. Warming at the sediment-water interface, coincident with salinity stratification, is potentially enhanced by the sun's irradiance that penetrates shallow and highly transparent waters (Gale et al. 2006). Hearn and Robson (2001) suggest that dissolved oxygen is influenced by vertical mixing of the surface water and the sediment oxygen demand. When extended salinity stratification appears, vertical mixing is inhibited and the consumption of oxygen by the sediments dominates. Pybus and Pybus (1980) demonstrated that surface waters in Murree contained more oxygen than the sediment/water interface, which was described as deoxygenated and characterised by hydrogen sulphide gas. Colonies of anoxigenic Chromatium sp. (purple sulphur bacteria) were observed on the sediment surface on many occasions during fieldwork and anoxic/suboxic conditions can be assumed at the sediment-water interface even in the shallow littoral zone. This is confirmed by the absence of the ostracod Cyprideis torosa in recent surveys (Roden and Oliver 2010), which does not tolerate low dissolved oxygen concentration (Holmes et al. 2007). Therefore, the reduction of oxygen at the sediment/water interface coupled with poikilohalinity constitutes a natural stressor for benthic fauna.

Murree has been described as a eutrophic coastal lake (e.g. Lansbury 1965; Healy et al. 1997), but chemical analyses suggest that the lake lies at the boundary between oligotrophic and mesotrophic conditions (Pybus and Pybus 1980; Roden and Oliver 2010). Therefore, Murree should be considered as a highly productive rather than a nutrient rich coastal lake. The formation of dense macroalgal beds, principally composed by Chara canescens and Lamprothamnion pauplosum, highlights the importance of the habitat (Bamber et al. 1992) and are responsible for the high degree of water clarity. In fact, macroalgae are capable of rapid nutrient uptake and influence the movement of dissolved nutrients across the sediment-water interface (Tyler et al. 2003) affecting phytoplankton production (McGlathery et al. 2001).

Recent climatic predictions indicate a possible relative sea level (RSL) rise of $0.5 \mathrm{~m}$ by 2100 (IPCC 2000; Sweeney et al. 2002; Fealy et al. 2010). A progressive increase in the RSL together with land submergence (Gehrels 2010) might lead to increased seawater overwash to Murree in the near future. Additionally, a permanent superficial connection with the sea might form to the south-west of the lake. This will potentially see a dramatic shift in lagoon hydrology and ecology.

\section{PALAEOECOLOGICAL RECONSTRUCTION}

Palaeolimnological reconstructions revealed a complex chronology and sedimentation regime in Lough Murree. The dating of the sediment confirms differences between adjacent cores, while a large gap in sedimentation and poorly preserved proxies (e.g. diatoms) limits historical inferences. However, despite these limitations the proxy data are indicative of coastal influences and suggest a hydrological shift from marine-brackish conditions to a poikilohaline system as described by modern hydrology.

\section{Chronology}

Establishing a sediment core chronology using a variety of dating methodologies and materials can be useful in palaeoenvironmental reconstructions (Enters et al. 2006; Saulnier-Talbot et al. 2009). However, in Murree, the chronological reconstruction was complicated because the two methods were performed on different sediment cores, and it was necessary to use a range of terrestrial and aquatic materials for ${ }^{14} \mathrm{C}$ AMS dating. Additionally, radiocarbon dates can be potentially biased by factors such as sediment reworking, marine reservoir effect (Ascough et al. 2009) and the hard water effect (Björck and Wohlfarth 2001; Pigati et al. 2010). Core LM1 was successfully dated using ${ }^{210} \mathrm{~Pb}$ methodologies indicating that the top $13 \mathrm{~cm}$ have been deposited during the past 115 years. Lagoons are considered to be among the most productive natural ecosystems in the world (Levin et al. 2001; Kennish and Paerl 2010) and high SARs 
were expected. However, modern chronology suggests exceptionally low SARs $(0.014 \mathrm{~g} \mathrm{~cm}$ year $\left.^{-1}, 0.126 \mathrm{~cm} \mathrm{year}^{-1}\right)$. Radiocarbon dates for four different materials in LM2 date to between 4100 year BP and 4600 year BP. The divergence between dating systems and the uniformity of the radiocarbon dates, therefore, suggest that there must be a hiatus in sedimentation in the lagoon.

\section{The evolution of Murree}

Rock/cobble barrier lagoons form as a result of incident wave energy, swash dynamics and tidal range and permit water exchange via percolation (Carter and Orford 1980; Orford 2005). Rock barriers can have both overground and underground hydrological connection to the sea and can isolate lagoons from the sea with falls in sea level and land uplift (Westman and Hedenström 2002; Lamb et al. 2006). Physical, chemical and biological sediment proxies from Murree generally suggest an evolution to more freshwater conditions, while a notable change point at $c .40 \mathrm{~cm}$ sediment depth is evident and may be coincident with the sediment hiatus. Changes in relative sea level, hydrological communication, open and enclosed basin formation and possible forcing mechanisms are explored in the following sections.

Past change in RSL over NW Europe is spatially complex and still unclear (Tooley 1993; Edwards 2006) and no detailed reconstruction of Galway Bay RSL is available. However, primary index points included in the Sea Level Database of Ireland (Brooks and Edwards 2006) suggest a rise from c. $-6 \mathrm{~m} c .7000$ cal. year BP to $c .-2 \mathrm{~m}$ approximately $5000 \mathrm{cal}$. year BP. A lower palaeo mean sea level of $-2.27 \mathrm{~m}$ is suggested from Cork and $-1.68 \mathrm{~m}$ for Donegal (the extreme north and south of the country) for the mid-Holocene period. Sand mixed with mud through core LM2 could suggest a constant contribution from the sea. However, a lower RSL would potentially correspond to lower lake salinity, lower sediment accumulation and more freshwater influence similar to modern conditions. Lower salinity, however, is not supported by the sediment proxies, which suggest brackish-marine conditions in the older LM2 sediments. High $\delta^{13} \mathrm{C}$-inferred salinity (19\%) could be indicative of an open or semi-enclosed coastal basin with constant or intermittent seawater inflow, while organic matter at the base of LM2 ( $c$. $9 \mathrm{C} / \mathrm{N})$ is most likely derived from algal sources, which have $\mathrm{C} / \mathrm{N}$ values typically between 4 and 10 (Müller and Voß 1999; Yamamuro 2000). C/N ratios of $c .9$ have been attributed to benthic algal communities in shallow water sediments (Sundbäck et al. 2000). Algae and macrophytes have a wide range of $\delta{ }^{15} \mathrm{~N}$ (Finaly and Kendall 2007) and values of c. $2 \%$ at the base of LM2 core are possibly representative of phytoplankton (Maksymowska et al. 2000; Rossi et al. 2010). Basal core diatom records have relatively high concentrations (9.00 $\times 10^{5}$ frustules $\mathrm{g}^{-1} \mathrm{WW}$ ), are mainly composed of benthic species and assemblages comprising marine and brackish taxa, including high levels of Paralia sulcata. Fossil foraminifera assemblages from Murree are typical of marginal marine environments (Murray 2006) and resemble those found in other lagoons (e.g. Cearreta et al. 2002; Avramidis and Kontopoulos 2009; Lloyd and Evans 2002; Horton and Murray 2007). The lower core foraminifera assemblages in Murree also suggest a more saline environment. Food availability is another key factor controlling foraminifera abundance (Altenbach 1992; Gooday 1994) and freshly deposited phytoplankton are known to stimulate foraminifera population growth (Lee 1980; Anderson et al. 1991). Higher foraminifera concentrations in LM2 are coincident with high diatom concentrations.

Therefore, older sediments in LM2 between $116 \mathrm{~cm}$ and $40 \mathrm{~cm}$ depth, dating to c. 4100-4600, were clearly more marine influenced in character. This could be explained by a superficial connection to the sea, or a breach/storm surge between the sea and lagoon, which subsequently led to sediment erosion and a hiatus in the lagoon sediment chronology.

A dramatic change point is evident in all physical, chemical and biological proxies at approximately $40 \mathrm{~cm}$ or $1500 \mathrm{AD}$ with extrapolation of the ${ }^{210} \mathrm{~Pb}$-derived accumulation rates. The change point is characterised by peaks in $\mathrm{LOI}_{550}$, $\mathrm{C}_{\text {org }}, \mathrm{C} / \mathrm{N}$ and elemental nitrogen, declines in $\delta^{13} \mathrm{C}$ and a trough in $\delta^{15} \mathrm{~N}$ suggesting a major change in sediment source. A sediment hiatus postulated above and/or basin isolation are possible explanations. Increases in productivity, change in allochthonous inputs and/or sediment reworking are possible consequences. Following the change point, the Murree sediments are clearly more organic and carbonate rich, while diatom and foraminifera concentrations decline and $\delta^{13} \mathrm{C}$-inferred salinities are lower.

Isolation of Murree from the adjacent ocean would have determined major changes in hydrochemistry. The lagoon would have been rendered more susceptible to underground freshwater influence. The increase in sediment carbonate (as $\mathrm{LOI}_{950}$ ) in LM2 could reflect a shift to a more hydrologically closed (endorheic) system, as the high carbonate content is typical of karstic lakes (Reed et al. 2008). Additionally, the formation of large charophyte beds might have enhanced sediment carbonates via calcification of plant stems and oospores during photosynthetic activity (Andrews et al. 2004). The reduction in organic $\delta^{13} \mathrm{C}$ may also reflect increased freshwater inflow via groundwater and superficial runoff. 
Increased lagoon productivity is suggested by high carbonates, organic matter $\left(\mathrm{LOI}_{550}\right)$ and $\delta^{15} \mathrm{~N}$. Today, Murree is a highly productive coastal lake with dense macrophytes, macroalgal mats and recurrent algal blooms (e.g. Pybus and Pybus 1980; Oliver 2005). The increase in $\delta^{15} \mathrm{~N}$ evident after the change point and recorded through LM1 could be a response to this increase in primary production. This supposition is consistent with the presence of both charcoal and $\mathrm{C} / \mathrm{N}$ ratios. Moreover, transfer of nitrogen to the sediment may additionally be as a result of the development of macroalgal beds evidenced by increases in Characeae oospores in the recent sediments. Microbial mats are concurrent with modern poikilohaline conditions in Murree today; however, no sediment proxies were used to directly infer their historical development. The development of microbial mats is made possible with the activity of $\mathrm{N}_{2}$-fixing organisms (Bergman et al. 1997) in protected, shallow, warm waters, with fluctuations in temperature and in salinity (Friedman and Sanders 1972; Walter 1976; Stal et al. 1996; Villbrandt and Stal 1996). The role of benthic macrophytes in coastal lagoon nutrient cycles has been discussed by many authors (e.g. Tyler et al. 2003; McGlathery et al. 2007; Lloret and Marin 2009). McGlathery et al. (2007) outline the importance of benthic macrophytes in coastal lagoon resistance to eutrophication via nutrient sequestration into plant biomass. A progressive increase in algal mats in Murree as a result of basin isolation might, therefore, account for the upcore reduction in diatom concentration.

Reduced $\delta^{13} \mathrm{C}$-inferred salinity $(9 \%)$, after the change point, is coincident with biological responses in the diatom, foraminifera and ostracod assemblages. While diatom records were biased by poor frustule preservation that made the fossil record fragmentary low valve concentrations and assemblages in the recent sediments confirm brackish-freshwater tolerant species. Similar species assemblages were found in infilled coastal lagoons (Robinson 1982; Cearreta et al. 2003), while P. sulcata was common and particularly abundant in organic rich coastal sediments (Zong 1997; Gebühr et al. 2009). In parallel, the foraminifera assemblages confirm a less saline environment. Additionally, progressive declines in foraminifera concentrations are evident, and this generally reflects a shift from marine/brackish to freshwater conditions in coastal transitional zones (e.g. Scott and Medioli 1980; Patterson et al. 1985; Cearreta et al. 2007). The decreases in foraminifera are paralleled by decreases in diatom concentrations also suggesting a change in the food base.

The abundance of Cyprideis torosa in LM1 and LM2 core top might be indicative of the formation of poikilohaline conditions. C. torosa is a euryhaline species capable of withstanding a wide salinity range
$(0.4 \%-150 \%$ o ) (e.g. Heip 1976; Schiewer 2008; Primavera et al. 2011). In particular, low diversity assemblages with a few or a single dominating species generally indicate stressed and unstable conditions (e.g. Mazzini et al. 1999; Frenzel and Boomer 2005; Mischke et al. 2010). Moreover, it is noteworthy that $C$. torosa cannot tolerate low oxygenated waters (Holmes et al. 2007). Therefore, the expansion of monospecific populations of $C$. torosa in Murree could be a response to basin isolation. This is supported by the population structure which, in older sediments, is represented by small juvenile instars only and is typical of exposed conditions (Whatley 1983; Penney 1987), while the presence of adults together with larval stages in the upper core sediments are typical of more protected systems (Penney 1987). Equal proportions of left- and right-oriented valves (Schellenberg 2007) and the presence of shell noding in response to reduced water salinity (e.g. van Harten 2000; Keyser 2005) support this hypothesis.

A further explanation for the change point could be an increase in land-derived material. A possible input from the catchment is suggested by increased $\mathrm{C} / \mathrm{N}$ ratio $(c .9-13 \mathrm{C} / \mathrm{N})$ evident in LM2 core top suggesting a possible contribution allochthonous organic matter (Müller and Voß 1999; Sundbäck et al. 2000; Balascio et al. 2011). $\delta^{13} \mathrm{C}$ values reflect $\mathrm{C}_{3}$ plants which are generally comprised between $-30 \%$ and $-23 \%$ (Michener and Kaufman 2007; Li et al. 2008). The increase of charcoal particles in the upper part of the Murree core also supports the idea of enhanced external loads of land-derived material and, furthermore, could indicate the presence of enhanced anthropogenic activity. In fact, firing may have played an important role in woodland clearance as described by Molloy and O'Connell (2004) on Inis Oírr (Aran Islands) between 4900-3690 cal. year BP and at Cappanawalla (c. $10 \mathrm{~km}$ from Murree; Fig. 1b) from 3520 cal. year BP (Feeser and O'Connell 2010). An upcore decreasing trend in the $\mathrm{C} / \mathrm{N}$ ratio is also evident through core LM1. The reduction might indicate a more recent decline in landderived organic material; additionally, sediment reworking might also be a possible cause. The $\mathrm{C} /$ $\mathrm{N}$ ratio decrease at the top of LM1 indicates a possible reduction of land-derived material during the past 115 years.

Lagoon isolation has been inferred for Norwegian (Mills et al. 2009; Balascio et al. 2011) and Scottish (Mackie et al. 2005; Mackie et al. 2007) basins, which transformed into freshwater coastal lakes as a result of isostacy or land uplift. However, natural forcing is unlikely since Irish coasts, with the exception of a small portion of Northern Ireland, are submergent (Gehrels 2010). Anthropogenic forcing is, therefore, more likely. A 
significant anthropogenic influence is evident in the northern Burren area since the Iron Age (c. 600 BC-AD 500) (Feeser and O'Connell 2010). Holmes et al. (2007) highlighted effects of Neolithic clearance of land on salinity and water level in An Loch Mór, a coastal lake on the nearby Inis Oírr (Aran Islands). In Murree, anthropogenic forcing is reflected by the increase in charcoal particles at the top of LM2 and in LM1. The construction of a coastal road on the Finavarra Peninsula (Pybus and Pybus 1980) and the erection of the Martello Tower between 1811 and 1814 AD (Kerrigan 1982) are other potential sources of disturbance causing isolation of the lake from the adjacent ocean.

\section{CONCLUSIONS}

This research tracked the ecological history of Lough Murree a modern-day brackish coastal lagoon in a karst limestone landscape. Modern hydrological data collected over two years explored salinity change due to coastal influence and tracked freshwater inputs. Hourly time series data revealed wide seasonal salinity variation, saline and temperature stratification and abrupt system change over the course of days. The detailed record of current hydrological change was extended through palaeolimnological reconstructions, which permitted inference of development and change of over c. 4500 years. Interpretation of historical change was limited by a complex chronology, which limits what can be said about the timing of evolutionary change. However, in general, the interpretation of sediment proxies in Murree conforms with the supposition by Pybus and Pybus (1980) that the lagoon was once surficially connected to the sea. Many physical, chemical and biological process and responses parallel those of isolation basins in Northern Europe, which transformed into freshwater coastal lakes as a result of land uplift. Natural forcing and anthropogenic influence are both posited as possible explanations. The surficial isolation of the lake from the ocean has potentially rendered Murree a more productive system with the formation of dense macroalgal beds mostly composed of lagoonal specialist species, which are able to tolerate poikilohaline conditions (Bamber et al. 1992).

\section{REFERENCES}

Airoldi, L. and Beck, M.W. 2007 Loss, status and trends for coastal marine habitats of Europe. In R.N. Gibson, R.J.A. Atkinson and J.D.M. Gordon (eds), Oceanography and marine biology: an annual review, 45, 345-405. Taylor and Francis.
Altenbach, A.V. 1992 Short term processes and patterns in the foraminiferal response to organic flux rates. Marine Micropaleontology 19, 129-39.

Anderson, O.R., Lee, J.J. and Faber, W.W. 1991 Collection, maintenance and culture methods for the study of living foraminifera. In J.J. Lee and O.R. Anderson (eds), Biology of foraminifera, 335-57. London. Academic.

Andrews, J.E., Coletta, P., Pentecost, A., Riding, R., Dennis, S., Dennis, P.F. and Spiro, B. 2004 Equilibrium and disequilibrium stable isotope effects in modern charophyte calcites: implications for palaeoenvironmental studies. Palaeogeography, Palaeoclimatology, Palaeoecology 204, $101-$ 14.

Appleby, P.G. and Oldfield, F. 1978 The calculation of ${ }^{210} \mathrm{~Pb}$ dates assuming a constant rate of supply of unsupported ${ }^{210} \mathrm{~Pb}$ to the sediment. Catena 5, 1-8.

Ascough, P.L., Cook, G.T. and Dugmore, A.J. 2009 North Atlantic marine C reservoir effects: implications for Late-Holocene chronological studies. Quaternary Geochronology 4, 171-80.

Avramidis, P. and Kontopoulos, N. 2009 Holocene evolution and sedimentation rate of Alikes Lagoon, Zakynthos Island, Western Greece: preliminary results. Earth 4, 23-29.

Balascio, N.L., Zhang, Z., Bradley, R.S., Perren, B., Dahl, S.O. and Bakke, J. 2011 A multi-proxy approach to assessing isolation basin stratigraphy from the Lofoten Islands, Norway. Quaternary Research 75, 288-300.

Bamber, R.N., Batten, S.D., Sheader, M. and Bridgwater, N.D. 1992 On the ecology of brackish water lagoons in Great Britain. Aquatic Conservation: Marine and Freshwater Ecosystems 2, 65-94.

Bamber, R.N., Gilliland, P.M. and Shardlow, E.A. 2001 Saline lagoons: a guide to their management and creation. Peterborough. English Nature.

Barlow, P.M. 2003 Ground water in freshwater-saltwater environments of the Atlantic coast. Reston, VA. US Geological Survey.

Battarbee, R., Jones, V., Flower, R., Cameron, N., Bennion, H., Carvalho, L. and Juggins, S. 2001 Diatoms. In J.P. Smol, H.J.B. Birks and W.M. Last (eds), Tracking environmental change using lake sediments: terrestrial, algal, and siliceous indicators, 155-202. Dordrecht. Kulwer Academic Publishers.

Bennett, K.D. 1996 Determination of the number of zones in a biostratigraphical sequence. New Phytologist 132, 155-70.

Bennett, K.D. 2008 Psimpoll v. 4.263. Available at http://chrono.qub.ac.uk/psimpoll/psimpoll.html (last accessed on 11 December 2013).

Bergman, B., Gallon, J.R., Ral, A.N. and Stal, L.J. $1997 \mathrm{~N}_{2}$ fixation by non-heterocystous cyanobacteria. FEMS Microbiology Reviews 19, 139-85.

Björck, S. and Wohlfarth, B. $2001{ }^{14} \mathrm{C}$ Chronostratigraphic techniques in paleolimnology. In W.M. Last and J.P. Smol (eds), Tracking environmental change using lake sediments: basin analysis, coring and chronological techniques, 205-45. Dordrecht. Kluwer.

Bonis, A. and Grillas, P. 2002 Deposition, germination and spatio-temporal patterns of charophyte 
propagule banks: a review. Aquatic Botany 72, 23548.

Brooks, A. and Edwards, R. 2006 The development of a sea-level database for Ireland. Irish Journal of Earth Sciences 24, 13-27.

Buzer, J.S. 1981 Diatom analyses of sediment from loughine, Co. Cork, Southwest Ireland. New Phytologist 89, 511-33.

Carter, R.W.G. and Orford, J.D. 1980 Gravel barrier genesis and management: a contrast. Proceedings, Coastal Zone, American Society of Civil Engineers 80, 1304-20.

Cassina, F., Dalton, C., Dillane, M., de Eyto, E. and Sparber, K. 2013 A multi-proxy palaeolimnological study to reconstruct the evolution of a coastal brackish lake (Lough Furnace, Ireland) during the late Holocene. Palaeogeography, Palaeoclimatology, Palaeoecology 383-384, 1-15.

Cave, R.R. and Henry, T. 2011 Intertidal and submarine groundwater discharge on the west coast of Ireland. Estuarine, Coastal and Shelf Science 92, 41523.

Cearreta, A., Alday, M., Freitas, M.C., Andrade, C. and Cruces, A. 2002 Modern foraminiferal record of alternating open and restricted environmental conditions in the Santo André lagoon, SW Portugal. Hydrobiologia 475-476, 21-27.

Cearreta, A., Cachão, M., Cabral, C.M., Bao, R. and Ramalho, M.D.J. 2003 Lateglacial and Holocne environmental changes in Portugese coastal lagoons 2: microfossils multiproxy reconstruction of the Santo André coastal area. The Holocene 13, 447-58.

Cearreta, A., Alday, M., Freitas, M.C. and Andrade, C. 2007 Postglacial foraminifera and palaeoenvironments of the Melides lagoon (SW Portugal): towards a regional model of coastal evolution. Journal of Foraminiferal Research 37, 125-35.

Combroux, I. and Bornette, G. 2004 Propagule banks and regenerative strategies of aquatic plants. Journal of Vegetation Science 15, 13-20.

CORINE. 1990 Corine land cover 1990 (CLC1990) and Corine land cover changes $1975-1990$ in a 10 $\mathrm{km}$ zone around the coast of Europe. Available at http://www.eea.europa.eu/data-and-maps/data/ corine-land-cover-1990-clc1990-and-corine-landcover-changes-1975-1990-in-a-10-km-zone-aroundthe-coast-of-europe (last accessed 11 December 2013).

De Deckker, P. 1982 Late quaternary ostracods from Lake George, New South Wales. Alcheringa 6, 30518.

Dolukhanov, P.M., Subetto, D.A., Arslanov, K.A., Davydova, N.N., Zaitseva, G.I., Kuznetsov, D.D., Ludikova, A.V., Sapelko, T.V. and Savelieva, L.A. 2010 Holocene oscillations of the Baltic Sea and Lake Ladoga levels and early human movements. Quaternary International 220, 102-11.

Emeis, K.C., Struck, U., Blanz, T., Kohly, A. and Voß, M. 2003 Salinity changes in the central Baltic Sea (NW Europe) over the last 10000 years. The Holocene 13, 411-21.

Enters, D., Kirchner, G. and Zolitschka, B. 2006 Establishing a chronology for lacustrine sediments using a multiple dating approach - a case study from the Frickenhauser see, central Germany. Quaternary Geochronology 1, 249-60.
Fealy, R., Allot, N., Broderick, C., De Eyto, E., Dillane, M., Erdil, R.M., Jennings, E., Mc Crann, K., Murphy, C., O’ Toole, C., Poole, R., Rogan, G., Ryder, L., Taylor, D., Whelan, K. and White, J. 2010 RESCALE: review and simulate climate and catchment responses at burrishoole. Project-based award, final summary report. Available at http:// www.marine.ie/NR/rdonlyres/59B563C6-FE5C46D8-B21A-D25E817C2244/0/RESCALEReview andSimulateClimateandCatchmentResponsesatBurr ishoole.pdf (last accessed on 11 December 2013).

Feeser, I. and O'Connell, M. 2010 Late Holocene land-use and vegetation dynamics in an upland karst region based on pollen and coprophilous fungal spore analyses: an example from the Burren, western Ireland. Vegetation History and Archaeobotany 19 , 409-26.

Finaly, J.C. and Kendall, C. 2007 Stable isotope tracing of temporal and spatial variability in organic matter sources to freshwater ecosystems. In R. Michener and K. Lajtha (eds), Stable isotopes in ecology and environmental science. Blackwell Publishing. Malden, MA; Oxford; Victoria.

Flower, R.J. and Likhoshway, Y.V. 1993 An investigation of diatom preservation in Lake Baikal. Fifth Workshop on Diatom Algae: diatom algae as indicators of changes in climate and environment, 77-78.

Flower, R.J. and Ryves, D.B. 2009 Diatom preservation: differential preservation of sedimentary diatoms in two saline lakes. Acta Botanica Croatica 68, 381-99.

Frenzel, P. and Boomer, I. 2005 The use of ostracods from marginal marine, brackish waters as bioindicators of modern and Quaternary environmental change. Palaeogeography, Palaeoclimatology, Palaeoecology 225, 68-92.

Friedman, G.M. and Sanders, J.H. 1972 Principles of sedimentology. Sedimentary processes. Wiley \& Sons.

Gale, E., Pattiaratchi, C. and Ranasinghe, R. 2006 Vertical mixing processes in Intermittently Closed and Open Lakes and Lagoons, and the dissolved oxygen response. Estuarine, Coastal and Shelf Science 69, 205-16.

Gebühr, C., Wiltshire, K.H., Aberle, N., van Beusekom, J.E.E. and Gerdts, G. 2009 Influence of nutrients, temperature, light and salinity on the occurrence of Paralia sulcata at Helgoland Roads, North Sea. Aquatic Biology 7, 185-97.

Gehrels, W.R. 2010 Late Holocene land- and sealevel changes in the British Isles: implications for future sea-level predictions. Quaternary Science Reviews 29, 1648-60.

Gooday, A. 1994 The biology of deep-sea foraminifera: a review of some advances and their applications in paleoceanography. Palaios 9, 14-31.

Healy, B. 2003 Coastal lagoons. In M.L. Otte (ed), Wetlands of Ireland: distribution, ecology, uses and economic value. Dublin. University College Dublin Press.

Healy, B., Oliver, G.A., Hatch, P. and Good, J. 1997 Coastal Lagoons in the Republic of Ireland: no. 10 Lough Murree. Ireland. National Parks and Wildlife Service, Department of the Environment, Heritage and Local Government. 
Hearn, C.J. and Robson, B.J. 2001 Inter-annual variability of bottom hypoxia in shallow Mediterranean Estuaries. Estuarine, Coastal and Shelf Science 52, 643-57.

Heip, C. 1976 The life-cycle of Cyprideis torosa (Crustacea, Ostracoda). Oecologia 24, 229-45.

Heiri, O., Lotter, A.F. and Lemcke, G. 2001 Loss on ignition as a method for estimating organic and carbonate content in sediments: reproducibility and comparability of results. Journal of Paleolimnology 25, 101-10.

Holmes, J.A. 2001 Ostracoda. In J.P. Smol, H.J.B. Birks and W.M. Last (eds), Tracking environmental change using lake sediments: zoological indicators, 12551. Dordrecht. Kluwer Academic Publishers.

Holmes, J., Jones, R., Haas, J.N., Mc Dermott, F., Molloy, K. and O'Connell, M. 2007 Multiproxy evidence for Holocene lake-level and salinity changes at An Loch Mór, a coastal lake on the Aran Islands, Western Ireland. Quaternary Science Reviews 26, 2438-62.

Horton, B.P. and Edwards, R.J. 2006 Quantifying Holocene sea-level change using intertidal foraminifera: lessons from the British Isles. Cushman Foundation for Foraminiferal Research 40, 97.

Horton, P.H. and Murray, J.W. 2007 The roles of elevation and salinity as primary controls on living foraminiferal distributions: Cowpen Marsh, Tees Estuary, UK. Marine Micropaleontology 63, 169-86.

IPCC 2000 Emissions scenarios. A Special Report of Working Group III of the Intergovernmental Panel on Climate Change available at https://www.ipcc. $\mathrm{ch} / \mathrm{pdf} /$ special-reports/spm/sres-en.pdf (last accessed on 11 December 2013).

Keatings, K.W., Hawkes, I., Holmes, J.A., Flower, R.J., Leng, M.J., Abu-Zied, R.H. and Lord, A.R. 2007 Evaluation of ostracod-based palaeoenvironmental reconstruction with instrumental data from the arid Faiyum Depression, Egypt. Journal of Paleolimnology 38, 261-83.

Kennish, M.J. and Paerl, H.W. 2010 Coastal lagoons: critical habitats of environmental change. In M.J. Kennish and H.W. Paerl (eds), Coastal lagoons: critical habitats of environmental change. CRC Press. Boca Raton, London, New York.

Kerrigan, P.M. 1982 The defences of Ireland 17931815: the west coast, Kerry to Sligo. An Cosantoir, 42, 39-44.

Keyser, D. 2005 Histological peculiarities of the noding process in Cyprideis torosa (Jones) (Crustacea, Ostracoda). Hydrobiologia 538, 95-106.

Krammer, K. and Lange-Bertalot, H. 1986 Bacillariophyceae. Naviculaceae. Stuttgard, Heidelberg and Berlin. Spektrum Akademisher Verlag.

Krammer, K. and Lange-Bertalot, H. 1988 Bacillariophyceae. Bacillariaceae, Epithemiaceae, Surerillaceae. Stuttgard, Heidelberg and Berlin. Spektrum Akademisher Verlag.

Krammer, K. and Lange-Bertalot, H. 1991a Bacillariophyceae. Centrales, Fragilariaceae, Eunotiaceae. Stuttgard, Heidelberg and Berlin. Spektrum Akademisher Verlag.

Krammer, K. and Lange-Bertalot, H. 1991b Bacillariophyceae. Achnanthaceae. Stuttgard, Heidelberg and Berlin, Spektrum Akademisher Verlag.
Krammer, K. and Lange-Bertalot, H. 2000 Bacillariophyceae: English and French translation of the keys. Heidelberg and Berlin. Spektrum Akademisher Verlag.

Krishnaswami, S., Lal, D., Martin, J.M. and Meybeck, M. 1971 Geochronology of lake sediments. Earth and Planetary Science Letters 15, 407-14.

Ladakis, M., Dassenakis, M. and Pantazidou, A. 2006 Nitrogen and phosphorus in coastal sediments covered by cyanobacteria mats. Journal of Soils and Sediments 6, 46-54.

Lamb, A.L., Wilson, G.P. and Leng, M.J. 2006 A review of coastal palaeoclimate and relative sea-level reconstructions using $\delta^{13} \mathrm{C}$ and $\mathrm{C} / \mathrm{N}$ ratios in organic material. Earth-Science Reviews 75, 29-57.

Lansbury, I. 1965 Notes on the Hemiptera, Coleoptera, Diptera and other invertebrates of the Burren, Co. Clare and Inishmore, Aran Islands. Proceedings of the Royal Irish Academy 64b, 89-115.

Lee, J.J. 1980 Nutrition and physiology of the foraminifera. In M. Levandowsky and S.H. Hunter (eds), Biochemistry and physiology of protozoa, 3, 4366. New York. Academic Press.

Levin, L.A., Bosch, D.F., Covich, A., Dahm, C., Erseus, C., Ewel, K.C., Kneib, R.T., Moldenke, A., Palmer, M.A., Snelgrove, P., Strayer, D. and Weslawski, J.M. 2001 The function of marine critical transition zones and the importance of sediment biodiversity. Ecosystems 4, 430-51.

Li, L., Yu, Z., Moeller, R.E. and Bebout, G.E. 2008 Complex trajectories of aquatic and terrestrial ecosystem shifts caused by multiple human-induced environmental stresses. Geochimica et Cosmochimica Acta 72, 4338-51.

Livingstone, D.A. 1955 A lightweight piston sampler for lake deposits. Ecology 36, 137-39.

Lloyd, J.M. and Evans, J.R. 2002 Contemporary and fossil foraminifera from isolation basins in northwest Scotland. Journal of Quaternary Science 17, 431-43.

Lloret, J. and Marín, A. 2009 The role of benthic macrophytes and their associated macroinvertebrate community in coastal lagoon resistance to eutrophication. Marine Pollution Bulletin 58, 1827-34.

Lloret, J., Marín, A. and Marín-Guirao, L. 2008 Is coastal lagoon eutrophication likely to be aggravated by global climate change? Estuarine, Coastal and Shelf Science 78, 403-12.

Mackie, E.A.V., Leng, M.J., Lloyd, J.M. and Arrowsmith, C. 2005 Bulk organic $\delta^{13} \mathrm{C}$ and $\mathrm{C} / \mathrm{N}$ ratios as palaeosalinity indicators within a Scottish isolation basin. Journal of Quaternary Science 20, 30312.

Mackie, E.A.V., Lloyd, J.M., Leng, M.J., Bentley, M.J. and Arrowsmith, C. 2007 Assessment of $\delta^{13} \mathrm{C}$ and $\mathrm{C} / \mathrm{N}$ ratios in bulk organic matter as palaeosalinity indicators in Holocene and Lateglacial isolation basin sediments, northwest Scotland. Journal of Quaternary Science 22, 579-91.

Maksymowska, D., Richard, P., Piekarek-Jankowska, H. and Riera, P. 2000 Chemical and isotopic composition of the organic matter sources in the gulf of Gdansk (Southern Baltic Sea). Estuarine, Coastal and Shelf Science 51, 585-98.

Mazzini, I., Anadon, P., Barbieri, M., Castorina, F., Ferreli, L., Gliozzi, E., Mola, M. and Vittori, 
E. 1999 Late Quaternary sea-level changes along the Tyrrhenian coast near Orbetello (Tuscany, central Italy): palaeoenvironmental reconstruction using ostracods. Marine Micropaleontology 37, 289311.

McGlathery, K.J., Aanderson, I.C. and Tyler, A.C. 2001 Magnitude and variability of benthic and pelagic metabolism in a temperate coastal lagoon. Marine Ecology Progress Series 216, 1-15.

McGlathery, K.J., Sundbäck, K. and Anderson, I.C. 2007 Eutrophication in shallow coastal bays and lagoons: the role of plants in the coastal filter. Marine Ecology Progress Series 348, 1-18.

Meisch, C. 2000 Freshwater Ostracoda of Western and Central Europe. Heidelberg - Berlin. Spektrum Akademischer Verlag.

Michener, R.H. and Kaufman, L. 2007 Stable isotope ratios as tracers in marine food webs: an update. In R. Michener and K. Lajtha (eds), Stable isotopes in ecology and environmental science, 238-82. Malden, MA; Oxford; Victoria. Blackwell Publishing.

Mills, K., Mackay, A.W., Bradley, R.S. and Finney, B. 2009 Diatom and stable isotope records of late-Holocene lake ontogeny at Indrepollen, Lofoten, NW Norway: a response to glacio-isostasy and Neoglacial cooling. The Holocene 19, 261-71.

Mischke, S., Schudack, U., Bertrand, S.B. and Leroy, S.A.G. 2010 Ostracods from a Marmara Sea lagoon (Turkey) as tsunami indicators. Quaternary International. In press.

Molloy, K. and O'Connell, M. 2004 Holocene vegetation and land-use dynamics in the karstic environment of Inis Oírr, Aran Islands, Western Ireland: pollen analytical evidence evaluated in light of the archaeological record. Quaternary International 113, 41-64.

Mullan, G. 2003 Caves of county Clare and South Galway. Bristol. University of Bristol Spelaeological Society.

Müller, A. and Voß, M. 1999 The palaeoenvironments of coastal lagoons in the southern Baltic Sea, II. $\delta^{13} \mathrm{C}$ and $\delta^{15} \mathrm{~N}$ ratios of organic matter - sources and sediments. Palaeogeography, Palaeoclimatology, Palaeoecology 145, 17-32.

Murray, J.W. 1979 British nearshore foraminiferids: keys and notes for the identification of the species. London, New York and San Francisco. Published for the Linnean Society of London and the Estuarine and Brackish-water Sciences Association by Academic Press.

Murray, J.W. 2006 Ecology and applications of benthic foraminifera. Cambridge University Press.

NPWS. 2001 Clew Bay complex SAC site synopsis. Ireland. National Parks and Wildlife Service, Department of the Environment, Heritage and Local Government.

Oliver, G.A. 2005 Seasonal changes and biological classification of Irish coastal lagoons. Unpublished Ph.D. thesis, University College Dublin.

Oliver, G.A. 2007 Coastal Lagoons (1150). N.P.W. Service. Conservation Status Assessment Report.

Orford, J.D. 2005 Gravel barriers. In M. Schwartz (ed), Encyclopedia of coastal science, 491-92. Dordrecht. Springer.
Oyama, M. and Takehara, H. 1967 Revised standard soil colour charts. Japan. Color Research Institute.

Patterson, R.T., Mc Kinnon, K.D., Scott, D.B. and Medioli, F.S. 1985 Arcellaceans (thecamoebians) in small lakes of New Brunswick and Nova Scotia: modern distribution and Holocene stratigraphic changes. Journal of Foraminiferal Research 15, 114-37.

Penney, D.N. 1987 Application of Ostracoda to sealevel studies. Boreas 16, 237-47.

Pigati, J.S., Jason, A.R. and Nekola, J.C. 2010 Radiocarbon dating of small terrestrial gastropod shells in North America. Quaternary Geochronology 5, 51932.

Primavera, M., Simone, O., Fiorentino, G. and Caldara, M. 2011 The palaeoenvironmental study of Alimini Piccolo lake enables a reconstruction of Holocene sea-level changes in southeast Italy. The Holocene 21, 553-63.

Pybus, C. and Pybus, M.J. 1980 An ecological study of Lough Murree, a brackish water lake in County Clare. Proceedings of the Royal Irish Academy 80b, 367-84.

Reed, J.M. 2007 The role of quantitative diatombased palaeolimnology in environmental archaeology. In M. Lillie and S. Ellis (eds), Wetland archaeology and environments. Regional issues, global perspectives, 198-210. Oxford. Oxbow.

Reed, J.M., Leng, M.J., Ryan, S., Black, S., Altinsaçli, S. and Griffiths, H.I. 2008 Recent habitat degradation in karstic Lake Uluabat, western Turkey: a coupled limnological-palaeolimnological approach. Biological Conservation 141, 2765-83.

Reimer, P.J., Baillie, M.G.L., Bard, E., Bayliss, A., Beck, J.W., Blackwell, P.G., Bronk Ramsey, C., Buck, C.E., Burr, G.S., Edwards, R.L., Friedrich, M., Grootes, P.M., Guilderson, T.P., Hajda, S.I., Heaton, T.J., Hogg, A.G., Hughen, K.A., Kaiser, K.F., Kromer, B., McCormac, F.G., Manning, S.W., Reimer, R.W., Richards, D.A., Southon, J.R., Talamo, S., Turney, C.S.M., van der Plicht, J. and Weyhenmeyer, C.E. 2009 INTCAL09 and MARINE09 radiocarbon age calibration curves, 0 50,000 years cal BP. Radiocarbon 51, 1111-50.

Renberg, I. and Hansson, H. 2008 The HTH sediment corer. Journal of Paleolimnology 40, 655-59.

Robinson, M. 1982 Diatom analysis of Early Flandrian lagoon sediments from East Lothian, Scotland. Journal of Biogeography 9, 207-21.

Roden, C. and Oliver, G. 2010 Monitoring and Assessment of Irish Lagoons for the purpose of the EU Water Framework Directive. Unpublished report prepared for the EPA.

Rossi, L., Costantini, M.L., Carlino, P., di Lascio, A. and Rossi, D. 2010 Autochthonous and allochthonous plant contributions to coastal benthic detritus deposits: a dual-stable isotope study in a volcanic lake. Aquatic Sciences 72, 227-36.

Ruiz, F., González-Regalado, M.L., Muñoz, J.M., Pendón, J.G., Rodríguez-Ramírez, A., Cáceres, L. and Rodríguez Vidala, J. 2003 Population age structure techniques and ostracods: applications in coastal hydrodynamics and paleoenvironmental analysis. Palaeogeography, Palaeoclimatology, Palaeoecology 199, 51-69. 
Ryves, D.B., Battarbee, R.W., Juggins, S., Fritz, S.C. and Anderson, J.N. 2006 Physical and chemical predictors of diatom dissolution in freshwater and saline lake sediments in North America and West Greenland. Limnology and Oceanography 51, 135568.

Saulnier-Talbot, É., Pienitza, R. and Stafford, T.W. 2009 Establishing Holocene sediment core chronologies for northern Ungava lakes, Canada, using humic acids (AMS ${ }^{14} \mathrm{C}$ ) and ${ }^{210} \mathrm{~Pb}$. Quaternary Geochronology 4, 278-87.

Savage, C., Leavitt, P.R. and Elmgren, R. 2010 Effects of land use, urbanization, and climate variability on coastal eutrophication in the Baltic Sea. Limnology and Oceanography 55, 1033-46.

Schellenberg, S.A. 2007 Marine ostracods. In S.A. Elias (ed), Encyclopedia of quaternary science, 2046-62. Elsevier.

Schiewer, U. 2008 Greifswalder Bodden, WismarBucht and Salzhaff. In U. Schiewer (ed.), Ecology of Baltic coastal waters. Berlin Heidelberg. Springer.

Scott, D.B. and Medioli, F.S. 1980 Post-glacial emergence curves in the Maritimes determined from marine sediments in raised basins. National Science and Engineering Research Council. Cambridge, New York, Port Melbourne, Madrid, Cape Town.

Scott, D.B., Schafer, C.T. and Medioli, F.S. 2007 Monitoring in coastal environments using foraminifera and thecamoebian indicators. Cambridge University Press.

Snoeijs, P. 1993 Intercalibration and distribution of diatom species in the Baltic Sea. Uppsala. Opulus Press.

Snoeijs, P. and Vilbaste, S. 1994 Intercalibration and distribution of diatom species in the Baltic Sea. Uppsala. Opulus Press.

Snoeijs, P. and Potapova, M. 1995 Intercalibration and distribution of diatom species in the Baltic Sea. Uppsala. Opulus Press.

Snoeijs, P. and Kasperovičienè, J. 1996 Intercalibration and distribution of diatom species in the Baltic Sea. Uppsala. Opulus Press.

Snoeijs, P. and Balashova, N. 1998 Intercalibration and distribution of diatom species in the Baltic Sea. Uppsala. Opulus Press.

Stal, L.J., Behrens, S.B., Villbrandt, M., van Bergeijk, S. and Kruyning, F. 1996 The biogeochemistry of two eutrophic marine lagoons and its effect on microphytobenthic communities. Hydrobiologia 329, 185-98.

Stuiver, M., Reimer, P.J. and Reimer, R.W. 2005 CALIB 6.0 [program and documentation]. Available at http://calib.qub.ac.uk/calib/ (last accessed 11 December 2013).

Sundbäck, K., Miles, A. and Göransson, E. 2000 Nitrogen fluxes, denitrification and the role of microphytobenthos in microtidal shallow-water sediments: an annual study. Marine Ecology Progress Series 200, 59-76.

Sweeney, J., Donnelly, A., Mc Elwain, L. and Jones, M. 2002 Climate change - indicators for Ireland.
EPA/ERTDI Project \# 2002-LS-5.2.2-M1 Final report to the EPA.

Talbot, M.R. 2001 Nitrogen isotopes in palaeolimnology. In W.M. Last and J.P. Smol (eds), Tracking environmental change using lake sediments: physical and geochemical methods, 401-39. Dordrecht. Kluwer Academic Press.

Thornton, S.F. and Mc Manus, J. 1994 Application of organic carbon and nitrogen stable isotope and $\mathrm{C} / \mathrm{N}$ ratios as source indicators of organic matter provenance in estuarine systems: evidence from the Tay Estuary, Scotland. Estuarine, Coastal and Shelf Science 38, 219-33.

Tooley, M.J. 1993 Long-term changes in eustatic sea level. In R.A. Warrick, E.M. Barrow and T.M.L. Wigley (eds), Climate and sea-level change: observations, projections and implications, 81-107. Cambridge. Cambridge University Press.

Tyler, A.C., McGlathery, K.J. and Anderson, I.C. 2003 Benthic algae control sediment: water column fluxes of organic and inorganic nitrogen compounds in a temperate lagoon. Limnology and Oceanography 48, 2125-37.

van Harten, D. 2000 Variable noding in Cyprideis torosa (Ostracoda, Crustacea): an overview, experimental results and a model from Catastrophe Theory. Hydrobiologia 419, 131-39.

Viaroli, P., Bartoli, M., Giordani, G., Magni, P. and Welsh, D.T. 2004 Biogeochemical indicators as tools for assessing sediment quality/vulnerability in transitional aquatic ecosystems. Conservation: Marine and Freshwater Ecosystems 14, 19-29.

Villbrandt, M. and Stal, L.J. 1996 The effect of sulphide on nitrogen fixation in heterocystous and non-heterocystous cyanobacterial mat communities. Algological Studies 83, 549-63.

Walter, M.R. 1976 Stromatolites, 790. Amsterdam. Elsevier.

Westman, P. and Hedenström, A. 2002 Environmental changes during isolation processes from the Litorina Sea as reflected by diatoms and geochemical parameters - a case study. Holocene 12, 531-40.

Whatley, R.C. 1983 The application of Ostracoda to palaeoenvironmental analysis. In R.F. Maddocks (ed), Applications of Ostracoda, Proceedings of the Eighth International Symposium on Ostracoda, July 26-29, 1982, 51-77. University Houston Geoscience, Houston, Texas.

Wolfe, A.P. 2001 Carbon and oxygen isotope analysis of lake sediment cellulose: methods and applications. In W.M. Last and J.P. Smol (eds), Tracking environmental change using lake sediment: physical and geochemical methods, 373-400. Amsterdam. Kluwer Academic Publishers.

Yamamuro, M. 2000 Chemical tracers of sediment organic matter origins in two coastal lagoons. Journal of Marine Systems 26, 127-34.

Zong Y. 1997 Implications of Paralia sulcata abundance in Scottish isolation basins. Diatom Research 12, 125-50. 